\title{
The Effect Of Good Corporate Governance, Work Life Balance, Talent Management And Person Organization Fit On Employee Performance At The Planning, Research And Development Agency Of Bukittinggi City
}

\author{
Robby Dharma $^{1 *}$, Lestari Gusnawati ${ }^{2}$ \\ ${ }^{1,2}$ Department of Management, Faculty of Economics and Business, Putra Indonesia University YPTK Padang \\ *email, robby_dharma@upiyptk.ac.id
}

\begin{abstract}
The purpose of this research journal is to find out how much "The Influence of Good Corporate Governance, Work Life Balance, Talent Management and Person Organization Fit on Employee Performance at the Planning, Research and Development Agency (Bapelitbang) of Bukittinggi City. Methods of collecting data through surveys, interviews, and questionnaires with a sample of 34 respondents. The analytical method used is Multiple Linear Regression Analysis.The results of data analysis concluded, partially there is a positive and significant effect of Good Corporate Governance on Employee Performance. Partially there is a positive and significant effect of work life balance on employee performance. Partially there is a positive and significant influence of Talent Management on Employee Performance. Partially there is a positive and significant effect of Personorganization Fit on Employee Performance. Simultaneously there is a positive and significant influence of Good Corporate Governance, Work Life balance, Talent Management, Personorganization Fit on Employee Performance. The contribution of Good Corporate Governance, Work Life balance, Talent Management, Personorganization Fit variables is 0.641 or $64.1 \%$ while the remaining $35.9 \%$ is influenced by other variables.
\end{abstract}

Keywords: Good Corporate Governance, Work Life balance, Talent Management, Person Organization Fit, Employee Performance.

\section{Introduction}

Every company has employees who are in charge of carrying out operational activities. In the product service process, which is dominated by humans, the relationship between systems within the organization which is a prerequisite for achieving an effective organization directly requires better human resource management capabilities. The most important factor in determining the success or failure of an organization is the human resource factor.

According to [1] said that human resource management is a planning, organizing, coordinating, implementing and supervising the procurement, development, provision of remuneration, integration, maintenance and separation of workers in order to achieve organizational goals. According to [2] Human resources (HR) is one of the important things to pay attention to in government sector agencies. Its existence is a determining factor in the success of an institution. If there are no human resources, the agency will not be able to carry out all its operational activities. The human resources in question are dedicated employees, who have the creativity and energy needed by the agency in order to achieve the expected goals.

Based on the opinions of the experts above, it can be concluded that human resource management is a science in managing and planning and processing relationships and the role of an individual or employee in carrying out responsibilities towards the company effectively and efficiently in achieving the goals desired by the organization or company. the role of human resources is a very important thing in determining the effectiveness of the running of a company. Human resources are needed in a competent and quality company, especially in the current era of globalization. In this era, all business organizations must be prepared to adapt and strengthen itself in order to compete so as to address the challenges in the future will come. Human resources in this case, employees must always play an active and dominant role in every activity of the organization because humans are the planners, behavior and determinants of the realization of the goals of an organization. The use of an effective workforce is the key towards improving employee performance so that a company policy is needed to motivate employees to be able to work more productively according to the plan that will be set. In general, performance is a result of work that will be achieved by an employee in carrying out the tasks that will be assigned to him. Performance is the result of employee behavior after carrying out activities or work activities. According to [2] Performance is the result obtained by an organization, both the organization is profit oriented and non profit oriented which is produced over a period of time. According to [1] performance is the end result of the energy and thoughts achieved by a person both in quality and quantity in doing a job. This means that performance is an action / activity to achieve the expected 
goals, objectives, vision and mission. Performance can also be with 34 employees. The total number of attendance for one said to be a combination of knowledge, abilities, attitudes, and month is 600 days, employees who are sick 22 days, employees motivations that can be assessed from the results of their work who are on leave of 15 days, outgoing service is 43 days, there obtained over a certain period of time.

is no internal service, then no information is available. In According to [3] Employee Performance is the result February 2021 with 34 employees. The total number of of work that can be achieved by a person or group of people in attendance for one month is 604 days, employees who are sick an organization, in accordance with their respective authorities 22 days, employees who are on leave for 5 days, out of office and responsibilities, in an effort to achieve the goals of the are 15 days, there is no internal service, then no information is organization concerned legally, not violating the law and in available. In March 2021 with 34 employees. The total number accordance with morals and ethics. of attendance for one month is 669 days, sick employees are In order for the objectives of the Bukittinggi City Planning, 16 days, employees are on leave for 33 days, outgoing services Research and Development Agency (BAPELITBANG) to be are 30 days, there are no internal services, then no information achieved, employees must have better performance, in addition is available.

to achieving the objectives of the Bukittinggi City Planning,

So here we can see that this will have an impact on Research and Development Agency (BAPELITBANG) which the implementation of employee duties and responsibilities , is prosperous, religious and cultured, employees are required the completion of work can be delayed and also the work to be able to complete duties and responsibilities effectively results will not be optimal which will have an impact on and efficiently. But in the company there are many problems employee performance at the Bukittinggi City Planning, that occur in the performance of employees. The decline in Research and Development Agency (BAPELITBANG ). The performance due to a lack of awareness of employees will be high level of employee absenteeism is one of the general liable to the duties and obligations as an employee. The indications of job stress and job satisfaction.

statement is based on employee attendance data. The statement is based on employee attendance data in October 2020 to March 2021 which is presented in table 1 below:

Table 1.1

Recapitulation of Presence Data for the Planning, Research and Development Agency for the City of Bukittinggi (BAPELITBANG ) Starting from October 2020 to March 2021

\begin{tabular}{|c|c|c|c|c|c|c|c|c|}
\hline \multirow{2}{*}{ M10NTH } & \multirow{2}{*}{$\begin{array}{c}\text { TOTAL } \\
\text { EMPLOYEE }\end{array}$} & \multicolumn{6}{|c|}{ PRESENCE } & \multirow{2}{*}{$\begin{array}{c}\text { T } \\
\text { OTAL }\end{array}$} \\
\hline & & $\mathrm{H}$ & S & C & DL & DD & TK & \\
\hline Otctber & 34 & 519 & 1 & 21 & 9 & 0 & 0 & 556 \\
\hline Norember & 34 & 618 & 26 & 22 & 48 & 0 & 0 & 714 \\
\hline Decernber & 34 & 331 & 15 & 16 & 80 & 8 & 0 & 42 \\
\hline January & 34 & 600 & 22 & 15 & 4) & 0 & 7 & 680 \\
\hline Febrouary & 34 & 64 & 22 & 5 & 15 & 0 & 0 & 646 \\
\hline Narch & 34 & 609 & 16 & 33 & 30 & 0 & 0 & 748 \\
\hline
\end{tabular}

Source: Office of the Planning, Research and Development Agency of Bukittinggi City (BAPELITBANG)

From the table above, it can be seen that there have been fluctuations (up and down) in employee attendance at the 1 . What is the effect of Good Corporate Governance on Bukittinggi City Planning, Research and Development Agency employee performance at the Research and Development (BAPELITBANG ) from the last six months, in October 2020 Planning Agency of Bukittinggi City ?

with a total of 34 employees. The total number of attendance 2. How does Work Life Balance affect employee performance for one month is 519 days, employees who are sick for 7 days, at the Research and Development Planning Agency of employees who are on leave for 21 days, out of office are 9 Bukittinggi City?

days, there is no internal service, then no information without 3 . What is the influence of Talent Management on employee any information. In November 2020 with 34 employees. The performance at the Research and Development Planning total number of attendance for one month is 618 days, sick Agency of Bukittinggi?

employees are 26 days, employees are on leave for 22 days, 4 . How is the influence of Person Organization Fit on outgoing services are 48 days, there are no internal services, employee performance at the Research and Development then no information is available. In December 2020 with 34 Planning Agency of Bukittinggi City ?

employees. The total number of attendance for one month is 5. What is the effect of Good Corporate Governance, Work 331 days, sick employees are 15 days, employees are on leave Life Balance, Talent Management and Person Organization for 16 days, outgoing services are 80 days, there are no internal Fit on employee performance at the Research and services, then no information is available. In January 2021 Development Planning Agency of Bukittinggi City? 


\section{Employee Performance}

According to [3] performance is the result of work that can be achieved by a person or group of people in an organization, in accordance with their respective authorities and responsibilities, in an effort to achieve the goals of the organization concerned legally, not violating the law and in accordance with morals and ethics.

According to [4] employee performance indicators are as follows:

1) Quality (Quality)

2) Quantity (Quantity)

3) Time (Term)

4) Cost suppression

5) Supervision

6) Relations between employees

\section{Good Corporate Governance (X1)}

According to [5] Good Corporate Governance (good corporate governance) is a principle that direct and control the enterprise in order to achieve a balance between the strength and authority to the company to provide accountability to stakeholders in particular, and stakeholders in general.

According to [6] Good Corporate Governance indicators ( good corporate governance) are described as follows:

1) Information Disclosure (Transparency)

2) Accountability (Accountability)

3) Accountability (Responsibilities)

4) Professional (Professional)

5) Independence (Independency)

6) Equality and Fairness (Fairness)

3. Work Life Balance (X2)

According to [7] Work-Life Balance (Balance Between Personal Life and Work) is a condition in which a person experiences a balanced attachment and satisfaction in his role as a worker and in his family.

According to [4] Work life Balance indicators include:

1) Time Balance

2) Engagement Balance

3) Satisfaction Balance

4. Talent Management (X3)

According to [8] Talent Management is a series of activities carried out by companies to find the right employees and place them in the right places through the process of identification, development, defense, and placement in appropriate positions.

According to [9] talent management indicators include:

1) Recruitment Process

2) Selection Process

3) Process Orientation

4) Educational Process

5) Training Process
6) Performance Management Process

7) Retention Acknowledgment Process

\section{Person Organization Fit (X4)}

According to [10] Person Organization Fit (the compatibility between individual employee values and organizational values ) is the similarity of the characteristics of each individual with an organization that has a function commensurate with the organizational culture in building individual commitment as well as individual guidelines in the organization.

According to [11] the Person Organization Fit indicator (conformity between individual employee values and organizational values) :

1) Value fit

2) Purpose fit

3) Meeting employee needs

4) Conformity of culture-personality characteristics

\section{Theoretical Framework}

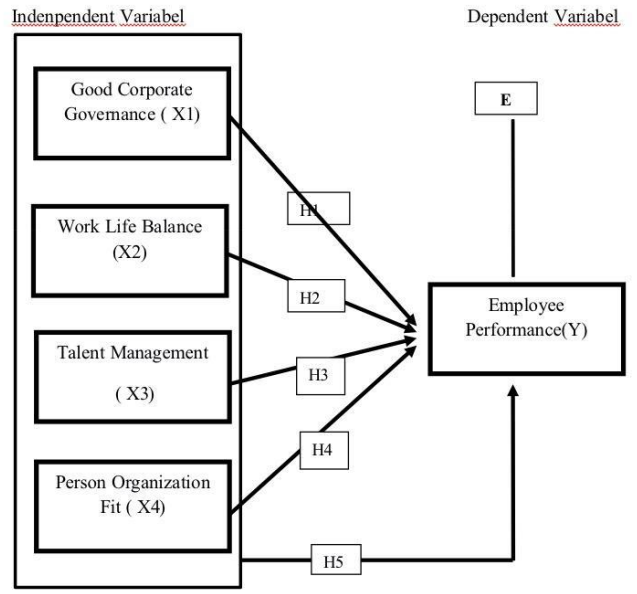

Figure 1.1

Hypothesis

Framework

The hypothesis is a short statement concluded from the literature review (theoretical basis and previous research), and is a temporary answer to the problem under study. In this study, hypotheses will be formulated to provide direction and guidance in conducting research. The hypotheses put forward in this study are:

H1 : It is suspected that Good Corporate Governance (X1) has a positive and significant influence on Employee Performance at the Research and Development Planning Agency (BAPELITBANG) Bukittinggi City

DOI: https://doi.org/10.35134/jbe.v7i1.73

Creative Commons Attribution 4.0 International License(CC BY 4.0) 
H2 : It is suspected that Work Life Balance (X2) has a positive and significant influence on employee performance at the Research and Development Planning Agency (BAPELITBANG) Bukittinggi City

H3 : It is suspected that Talent Management (X3) has a positive and significant influence on employee performance at the Research and Development Planning Agency (BAPELITBANG) Bukittinggi City

The Good Corporate Governance variable has a calculated $r$ value greater than the $r_{\text {table }}$ value, at the significance level $(\mathrm{p})=5 \%(0.05), \mathrm{Df}=\mathrm{n}-2$, so $34-2=32$ which shows the number 0.338 , in accordance with testing criteria regarding whether it is valid or not. From this comparison, all items of the Good Corporate Governance variable statement are declared " valid".

From the Work Life balance variable, the $\mathrm{c}_{\text {calculated }} \mathrm{r}$ value H4 : It is suspected that Person Organization Fit (X4) has a is greater than the $r_{\text {table }}$ value , at the significance level $(p)=5 \%$ positive and significant influence on Employee Performance in ( 0.05$)$, Df $=n-2$, so 34-2 $=32$ which shows the number 0.338 Research and Development Planning (BAPELITBANG), in accordance with testing criteria regarding whether it is Bukittinggi City

H5 : It is suspected that Good Corporate Governance (X1), Work Life Balance (X2), Talent Management (X3) and Person Organization Fit (X4) together have a positive and significant influence on Employee Performance at the City Research and Development Planning Agency (BAPELITBANG) Bukittinggi

\section{Method}

The population used in this study were employees of the Planning, Research and Development Agency for the City of Bukittinggi. While the data used as a sample in this study is data on the implementation of Good Corporate Governance, Work Life Balance, Talent Management and Person Organization Fit on Employee Performance at the Research and Development Planning Agency of Bukittinggi City.

\subsection{Data Instrument Test}

\subsubsection{Validity and Reliability Test}

The validity test is to determine the level of validity and the questionnaire instrument used in collecting data. This validity test is carried out to determine whether the items presented in the questionnaire are really able to reveal with certainty what will be studied. The test uses two sides with a significant level of 0.05 to interpret the results of the validity test, because what is used is:

1. If the calculaced $r$ value is greater than the $r_{\text {table }}$ value, then the instrument or statement items are declared valid and can be used.

2. If the $e_{\text {calculatcd }} r$ value is less than the $e_{\text {able }} r$ value, then the instrument or statement items are declared invalid and cannot be used.

After processing the data using the SPSS 16.0 system, the results of the validity test are obtained as follows:

\section{a . Employee Performance Variable Validity}

From the Employee Performance variable, the calculatcd $\mathrm{r}$ value is greater than the $r_{\text {table }}$ value, at the significance level (p) $=5 \%(0.05), \mathrm{Df}=\mathrm{n}-2$, so $34-2=32$ which shows the number 0.338 , according to the criteria testing whether it is valid or not. From this comparison, all items of the Employee Performance variable statement are declared " valid ".

\section{b . Good Corporate Governance Variable Validity}

valid or not. From this comparison, all items in the Work Life balance variable statement are declared " valid ".

\section{d. Talent Management Variable Validity}

From the Talent Management variable, the calculated $\mathrm{r}$ value is greater than the $r_{\text {table }}$ value, at the significance level $(p)$ $=5 \%(0.05), \mathrm{Df}=\mathrm{n}-2$, so $34-2=32$ which shows the number 0.338 , according to the criteria testing whether it is valid or variable statement are declared " valid ".

\section{e . Validity of Person Organization Fit . Variable}

From the Personorganization Fit variable, the calculatad $\mathrm{r}$ value is greater than the $r_{\text {table }}$ value, at the significance level (p) $=5 \%(0.05), \mathrm{Df}=\mathrm{n}-2$, so $34-2=32$ which shows the number 0.338 , according to the criteria testing whether it is valid or not. From this comparison, all items of the Personorganization Fit variable statement are declared " valid ".

\subsubsection{Descriptive Test Results of Research} Variables

This study uses the variables of Good Corporate Governance, Work Life balance, Talent Management, Personorganization Fit as the independent variable, while the Employee Performance variable as the dependent variable. The following will describe the respondents' answers to each research variable as follows:

\section{Frequency Distribution of Respondents' Answers to Employee Performance Variable Statement Instruments}

In this study, the Employee Performance variable is operationalized using 12 statement instruments, the statement instrument can be seen in table 1.2 below:

Table 1.2

Frequency Distribution of Respondents' Answers to Employee Performance Variable Statement Instruments not. From this comparison, all items of the Talent Management 


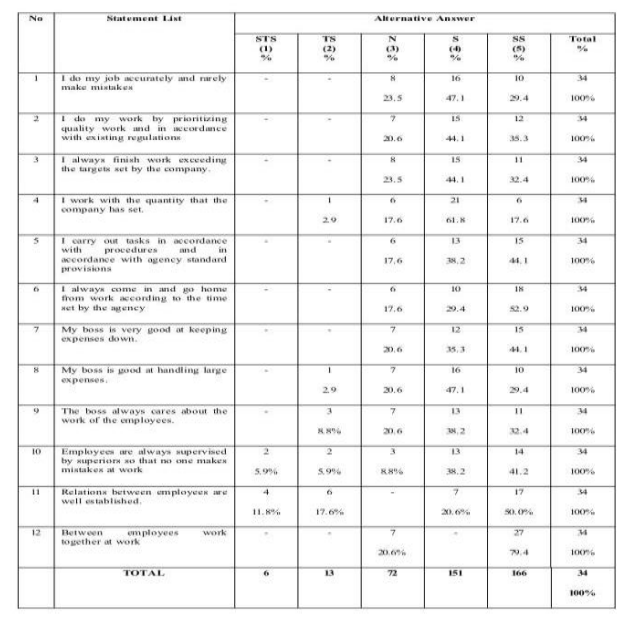

Source: Primary Data Processing Results , SPSS 16.0 Windows Evaluation Version

Based on the frequency distribution of respondents answers to the Employee Performance variable statement, it can be seen that the majority of research respondents gave answers in the "Strongly Agree" category.

2. Frequency Distribution of Respondents' Answers to the Good Corporate Governance Variable Statement Instrument

In this study, the Good Corporate Governance variable is operationalized using 12 statement instruments, the statement instruments can be seen in table 1.3 below:

Table 1.3

Frequency Distribution of Respondents' Answers to the Good Corporate Governance Variable Statement Instrument

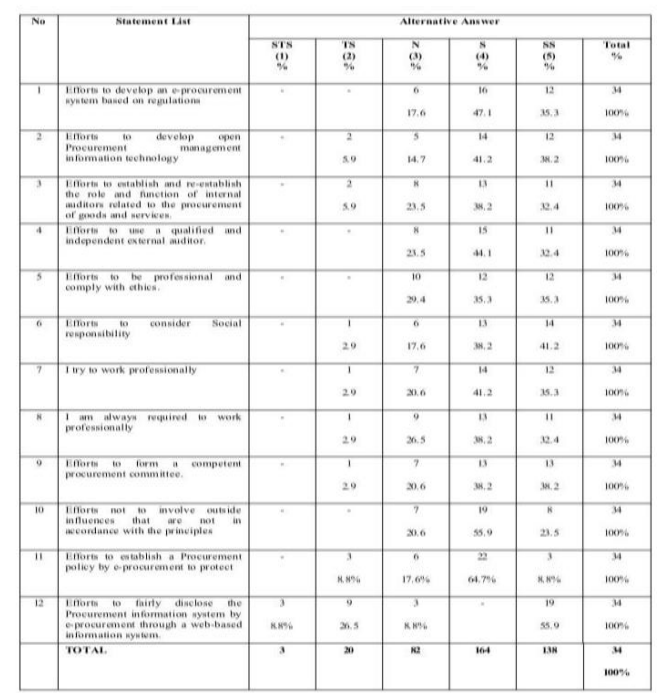

Source: Primary Data Processing Results , SPSS 16.0 Windows Evaluation Version

Based on the frequency distribution of respondents' answers to the statement of the Good Corporate Governance variable, it can be seen that the majority of research respondents gave answers in the "Strongly Agree" category.

\section{Frequency Distribution of Respondents' Answers to the Work Life Balance Statement Instrument}

In this study, the Work Life balance variable is operationalized using 6 statement instruments, the statement instruments can be seen in table 1.4 below:

Table 1.4

\section{Frequency Distribution of Respondents' Answers to the Work Life Balance Statement Instrument}

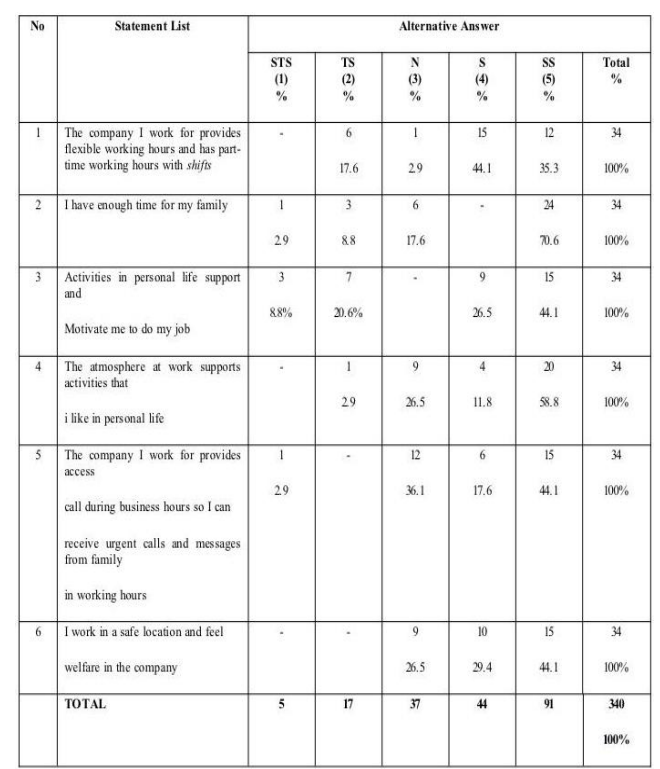

Source: Primary Data Processing Results , SPSS 16.0 Windows Evaluation Version

Based on the frequency distribution of respondents' answers to the statement of the Work Life balance variable, it can be seen that the majority of research respondents gave answers in the "Strongly Agree" category.

\section{Frequency Distribution of Respondents' Answers to the Talent Management Variable Statement Instrument}

In this study, the Talent Management variable was operationalized using 14 statement instruments, the statement instruments can be seen in table 1.5 below:

Table 1.5

Frequency Distribution of Respondents' Answers to the Talent Management Variable Statement Instrument

DOI: https://doi.org/10.35134/jbe.v7i1.73 


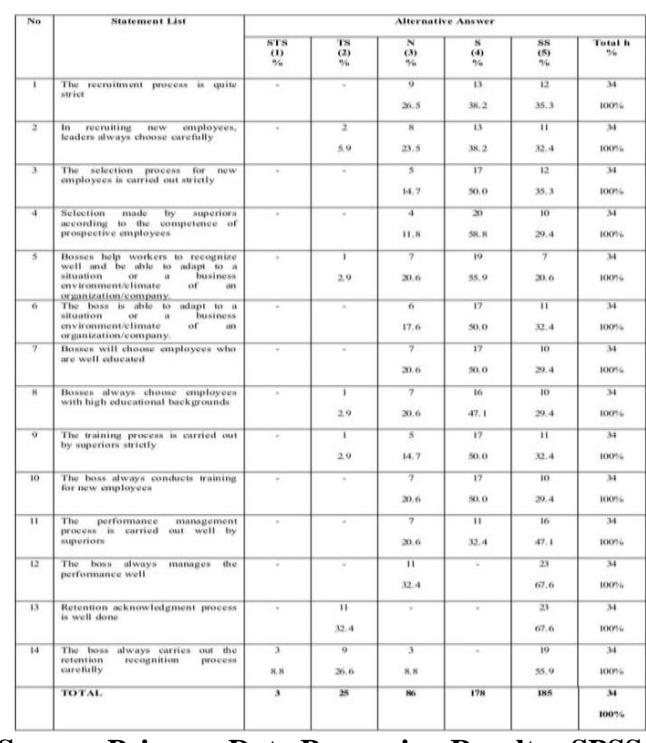

Source: Primary Data Processing Results , SPSS 16.0 Windows Evaluation Version

Based on the frequency distribution of respondents' answers to the Talent Management variable statement, it can be seen that the majority of research respondents gave answers in the "Agree" category.

5. Frequency Distribution of Respondents' Answers to the Personorganization Fit . Variable Statement Instrument

In this study, var iabel Personorganization Fit operationalized using instruments 8 statement, the statement of instruments can be seen in table 1.6 below:

Table 1.6

Frequency Distribution of Respondents' Answers to the Personorganization Fit . Variable Statement Instrument

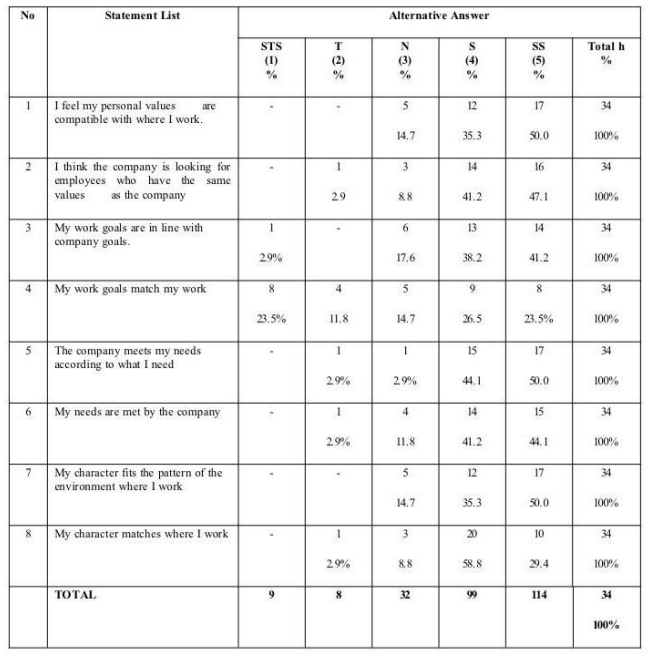

Source: Primary Data Processing Results , SPSS 16.0 Windows Evaluation Version

Based on the frequency distribution of respondents' answers to the Personorganization Fit variable statement, it can be seen that the majority of research respondents gave answers in the "Strongly Agree" category.
Based on the frequency distribution of respondents' answers to the Personorganization Fit variable statement, it can be seen that the majority of research respondents gave answers in the "Strongly Agree" category.

\subsection{Multiple Linear Regression Analysis Results}

Table 1.7

Multiple Linear Regression Analysis of Good Corporate Governance, Work Life Balance, Talent Management, Personorganization Fit on Employee Performance

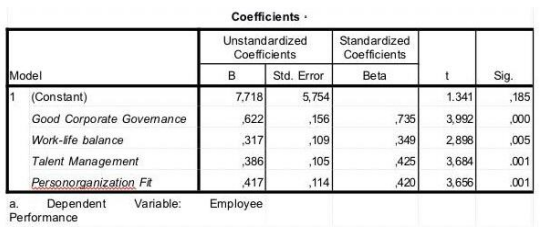

Based on table 1.7 above, it can be seen that the regression equation is:

$$
\begin{gathered}
\mathrm{Y}=7.718+0,622 \mathrm{X} 1+0,317 \mathrm{X} 2+0,386 \mathrm{X} 3+0,417 \mathrm{X} 4 \\
+\mathrm{e}
\end{gathered}
$$

Interpretations based on these equations can be interpreted as follows:

1. The constant of 7.718 means that if there is no Good Corporate Governance, Work Life balance, Talent Management, Personorganization Fit, the Employee Performance remains at a constant of 7.718.

2. Positive regression coefficient of 0.622 means that if Good Corporate Governance is increased by one unit, assuming Work Life balance, Talent Management, Personorganization Fit are ignored, it will result in an increase in Employee Performance of 0.622 .

3. Positive regression coefficient of 0.317 means that if Work Life balance is increased by one unit, assuming Good Corporate Governance , Talent Management, Personorganization Fit are ignored, it will result in an increase in Employee Performance of 0.317.

4. Positive regression coefficient of 0.386 means Talent Management if it is increased by one unit, assuming Good Corporate Governance, Work Life balance, Personorganization Fit are ignored, it will result in an increase in Employee Performance of 0.386.

5. Positive regression coefficient of 0.417 means Personorganization Fit if it is increased by one unit, assuming Good Corporate Governance, Work Life balance, Talent Management, Empathy are ignored, it will result in an increase in Employee Performance of 0.417 .

\section{Result}

\subsection{Partial Test (t Test)}

The $t$ test is intended to test the significant effect of the independent and dependent variables partially. Where this test compares the significant probability with an alpha of 0.05 . From the results of this test when the probability is significantly smaller than the alpha of 0.05 , the obtained $\mathrm{H}_{\text {o }}$ rejected and $\mathrm{H}_{\mathrm{a}}$ accepted, meaning there is a significant and if the probability is greater than the 0.05 alpha then $\mathrm{H}_{\mathrm{o}}$ accepted and $\mathrm{H}$ a rejected, meaning no connection. The degrees of freedom (df) nk 1 are $34-4-1=29$ ( $n$ is the number of respondents and $\mathrm{k}$ is the number of independent variables) so that the results obtained for the $\mathrm{t}$-table are 2.045 . 
Based on table 1.8 the following is an explanation of the $t$ test

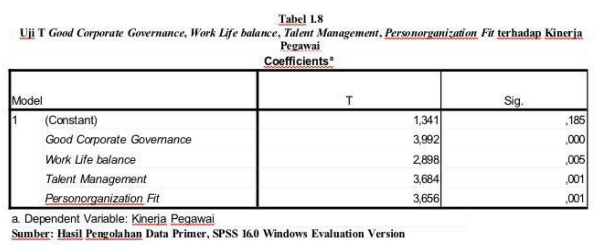

1. The Influence of Good Corporate Governance on Employee Performance.

From table 1.8 above, it can be seen that the t-count is 3.992 and the $\mathrm{t}$-table is 2.045 where the $\mathrm{t}$-count is greater than $\mathrm{t}$-table $(3.992>2.045)$ or a small significant level of alpha $(0.000<$ 0.05 ) then it can be obtained that $\mathrm{H}_{0 \text { is }}$ rejected $\mathrm{Ha}$ is accepted . 2. Effect of Work Life Balance on Employee Performance.

From table 1.8 above, it can be seen that the t-count is 2.898 and $\mathrm{t}$-table is 2.045 where the $\mathrm{t}$-count is greater than $\mathrm{t}$-table $(2.898>2.045)$ or the level is significantly smaller than alpha $(0.005<0.05)$, then it can be obtained that $\mathrm{H}_{0 \text { is }}$ rejected. Ha accepted.

3. Effect of Talent Management on Employee Performance From table 1.8 above, it can be seen that the t-count is 3.684 and the $\mathrm{t}$-table is 2.045 where the $\mathrm{t}$-count is greater than $\mathrm{t}$-table $(3.684>2.045)$ or the level is significantly less than alpha $(0.001<0,05)$ then it can be obtained $\mathrm{H}_{0}$ rejected $\mathrm{Ha}$ accepted. 4. Effect of Personorganization Fit on Employee Performance From table 1.8 above, it can be seen that the t-count is 3.656 and the t-table is 2.045 where the $\mathrm{t}$-count is greater than $\mathrm{t}$-table $(3.656>2.045)$ or the level is significantly smaller than alpha $(0.001<0,05)$ then it can be obtained $\mathrm{H}_{0}$ rejected $\mathrm{Ha}$ accepted. 3.4.2 Simultaneous Test $(\mathbf{F})$

The regression coefficient test was jointly carried out with the $\mathrm{F}$ test (ANOVA). This test is used to determine whether the independent variables together have a significant effect on the dependent variable. Or to find out whether the regression model can be used to predict the dependent variable or not. Significant means that the relationship that occurs can apply to the population (can be generalized). The test was carried out with the $\mathrm{F}$ test (ANOVA). The $\mathrm{F}$ test uses a significant level of 0.05 (2-sided test) with $95 \%$ degrees of freedom, alpha $=5 \%$, df 1 (number of variables -1 ) or $5-1=4$, and df $2(n k-1)$ or 34- 4-1 = 29, then the result obtained for $F$ is 2.70 .

The F test is intended to test the hypothesis of the research which states that the variables of Good Corporate Governance, Work Life balance, Talent Management, Personorganization Fit have a significant influence on employee performance. The results of joint hypothesis testing can be seen in table 1.9 as follows:

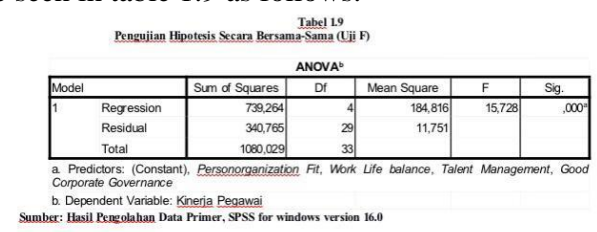

From table 1.9 above, it can be seen that this test was carried out by comparing the $F$ value with $F$ because the $F$ value was greater than the $\mathrm{F}$ value $(15.728>2.70)$. F value 15,728 with a significant level of 0.000 less than $5 \%$. Then Ho is rejected and $\mathrm{Ha}$ is accepted, which means that this is done jointly between Good Corporate Governance, Work Life balance, Talent Management, Personorganization Fit on Employee Performance.

\subsubsection{Coefficient of Determination (R2)}

Analysis of the coefficient of determination in multiple linear regression is used to determine the percentage of the contribution of the influence of the independent variables consisting of Good Corporate Governance, Work Life balance, Talent Management Personorganization Fit together on employee performance.

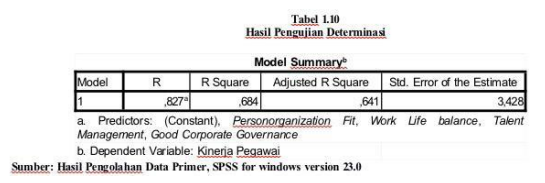

Based on table 4.24 above, the Adjusted R Square figure of 0.641 shows that the contribution of the Good Corporate Governance, Work Life balance, Talent Management, Personorganization Fit variables is 0.641 or $64.1 \%$ while the remaining $35.9 \%$ is influenced by other variables.

\section{Conclusion}

From the previous discussion, some conclusions can be drawn as follows:

1. That partially there is a positive and significant effect of Good Corporate Governance on Employee Performance. Where t-count is greater than t-table $(3.992>2.045)$ or a small significant level of alpha $(0.000<0.05)$ then it can be obtained that $\mathrm{HO}$ is rejected. Ha is accepted.

2. That partially there is a positive and significant effect of Work Life balance on Employee Performance. Where the tcount is greater than t-table $(2.898>2.045)$ or the level is significantly smaller than alpha $(0.005<0.05)$, then it can be obtained that $\mathrm{HO}$ is rejected. Ha is accepted.

3. Whereas partially there is a positive and significant influence of Talent Management on Employee Performance. Where the $t$-count is greater than the t-table $(3.684>2.045)$ or the level is significantly less than alpha $(0.001<0.05)$, it can be obtained that $\mathrm{HO}$ is rejected. Ha is accepted.

4. Whereas partially there is a positive and significant influence on Personorganization Fit on Employee Performance. Where the t-count is greater than t-table (3.656 > $2.045)$ or the level is significantly less than alpha $(0.001<$ $0.05)$, it can be obtained that $\mathrm{H} 0$ is rejected. Ha is accepted.

5 . Whereas simultaneously there is a positive and significant influence of Good Corporate Governance, Work Life balance, Talent Management, Personorganization Fit on Employee Performance. Where the value of $F$ is greater than the value of $\mathrm{F}(15.728>2.70)$. F value 15,728 with a significant level of 0.000 less than $5 \%$. Then obtained Ho is rejected and $\mathrm{Ha}$ is accepted.

6. The contribution of Good Corporate Governance, Work Life balance, Talent Management, Personorganization Fit variables is 0.641 or $64.1 \%$ while the remaining $35.9 \%$ is influenced by other variables.

\section{REFERENCES}

D. N. Syah, R. Hasbullah, and S. Solehudin, "Pengaruh Good Corporate Governance terhadap Kinerja Karyawan PT. Pupuk Kujang Cikampek," JBMP (Jurnal Bisnis, Manaj. dan Perbankan), vol. 4, no. 1, p. 22, 2019, doi: 10.21070/jbmp.v4i1.1899.

G. A. Setyawan, "Pengaruh Good Corporate Governance, Gaya Kepemimpinan, Motivasi, Kompensasi, Dan

DOI: https://doi.org/10.35134/jbe.v7i1.73

Creative Commons Attribution 4.0 International License(CC BY 4.0) 
Budaya Organisasi Terhadap Kinerja Karyawan Di Balaikota Surakarta," pp. 1-27, 2017, [Online]. Available: https://ci.nii.ac.jp/naid/40021243259/.

A. Minarika, R. S. Purwanti, and A. Muhidin, "Pengaruh work family conflict dan work life balance terhadap kinerja karyawan ( suatu studi pada pt . pacific eastern coconut utama pangandaran ) pendahuluan Pada era globalisasi saat ini , persaingan antar perusahaan baik itu perusahaan BUMN ataupun peru," vol. 2, pp. 111, 2020.

D. Dina, "Pengaruh Work-Life Balance Terhadap Kinerja Karyawan di KUD Minatani Brondong Lamongan," J. Indones. Membangun, vol. 17, no. 2, pp. 184-199, 2018.

lucia maria aversa Villela, "Implementasi good corporate governance dalam meningkatkan kinerja karyawan di bni parepare (Analisis Manajemen Syariah)," $J$. Chem. Inf. Model., vol. 53, no. 9, pp. 1689-1699, 2020.

Q. Amir Hamzah, MM., "Pengaruh kepemimpinan , motivasi dan good corporate sekretariat perusahaan pt pupuk sriwidjaja," vol. 6, no. 2, pp. 45-62, 2020.

F. Saifullah, "Pengaruh Work-Life Balance dan Flexible Work Arrangement Terhadap Kinerja Karyawati Muslimah Konveksi," BISNIS J. Bisnis dan Manaj. Islam, vol. 8, no. 1, p. 29, 2020, [Online]. Available: https://journal.iainkudus.ac.id/index.php/Bisnis/articl e/view/6762.

N. K. Karina and I. K. Ardana, "Pengaruh talent management terhadap kinerja karyawan dengan komitmen organisasi sebagai variabel moderasi pada karyawan," e-jurnal manaj. univ. udayana, 2020, doi: 10.24843/ejmunud.2020.v09.i02.p05.

S. S. Nugrahatamala and D. A. Fadili, "Pengaruh manajemen talenta dan manajemen pengetahuan terhadap kinerja karyawan The influence of talent management and knowledge management on employee performance," vol. 23, no. 1, pp. 39-45, 2021.

I. Crislianti, F. Ekonomi, and D. A. N. Bisnis, "Organisasi sebagai variabel moderasi ( studi pada bank bri syariah KC Semarang ) SKRIPSI," 2020.

D. S. Wahyuni, “Analisis pengaruh person organization fit (po fit) terhadap kinerja karyawan bnI SYARIAH (Studi Pada Bank BNI Syariah KC. Tanjung Karang)," SELL J., vol. 5, no. 1, p. 55, 2020. 